Anchundia, D., K. P. Huyvaert, and D. J. Anderson. 2014. Chronic lack of breeding by Galápagos Blue-footed Boobies and associated population decline. Avian Conservation and Ecology 9(1): 6. http://dx.doi.org/10.5751/ACE-00650-090106

Copyright (C) 2014 by the author(s). Published here under license by the Resilience Alliance.

Research Paper

\title{
Chronic lack of breeding by Galápagos Blue-footed Boobies and associated population decline
}

\author{
David Anchundia ${ }^{1}$, Kathryn P. Huyvaert ${ }^{2}$ and David J. Anderson ${ }^{1}$ \\ ${ }^{1}$ Wake Forest University, ${ }^{2}$ Colorado State University
}

\begin{abstract}
A survey of Blue-footed Boobies (Sula nebouxii excisa) throughout the taxon's range in Galápagos, Ecuador found 6400 adults, compared to a rough estimate of 20,000 in the 1960s. Few pairs bred in 2011-2013 and almost no birds in juvenile plumage were seen. Long-term data suggest that poor breeding began in 1998. Lack of recruitment over this period would mean that the current population is mostly elderly and experiencing senescent decline in performance. Anthropogenic effects such as introduced predators are unlikely to explain this decline because islands with and without such factors exhibited the same low breeding. The poor reproduction seems to be linked to diet. Previous work indicated that sardine and herring (Clupeidae) supported successful breeding, but these fish were mostly absent from the diet during this study, except in the central part of Galápagos, where most breeding attempts during this study occurred. Elsewhere in the eastern Pacific sardine abundance has decreased dramatically by natural processes in the last 15 years, as part of a well-documented and apparently natural cycle. This cyclic change in abundance provides a possible explanation for the recent demographic changes in Blue-footed Boobies in Galápagos. Whether natural or anthropogenic in origin, the implications of senescent decline in breeding ability and survival are dramatic for this genetically distinct icon of biodiversity and ecotourism.
\end{abstract}

\section{Absence chronique de reproduction chez le Fou à pieds bleus des Galápagos et déclin inhérent de la population}

RÉSUMÉ. Un inventaire du Fou à pieds bleus (Sula nebouxii excisa) dans l'ensemble de l'aire occupée aux Galápagos, en Équateur, fait état d' 6 400 adultes, comparativement aux 20000 estimés grossièrement dans les années 1960. Seulement quelques couples se sont reproduits en 2011-2013 et presque aucun oiseau en plumage juvénile n'a été observé. Les données à long terme indiquent que la reproduction est mauvaise depuis 1998. Le manque de recrutement durant la période 1998-2013 laisse supposer que la population actuelle serait surtout constituée de vieux individus aux performances reproductrices déclinantes en raison du phénomène de sénescence. Les causes de source anthropique, comme les prédateurs introduits, n'expliquent vraisemblablement pas ce déclin, car toutes les îles, avec ou sans prédateurs, présentent le même faible taux de reproduction. Ce faible taux semble plutôt lié à l'alimentation. Ainsi, des études antérieures ont révélé que les sardines et les harengs (Clupeidae) constituaient la base de l'alimentation d'individus s'étant reproduits avec succès dans le passé; or, ces poissons étaient pratiquement absents de l'alimentation des fous lors de notre étude, hormis dans le centre des Galápagos où la plupart des tentatives de reproduction se sont produites. Ailleurs dans l'est du Pacifique, le nombre de sardines a diminué dramatiquement durant les quinze dernières années, selon un cycle bien documenté et apparemment naturel. Il est donc possible que ce changement cyclique de l'abondance des poissons soit responsable des changements démographiques récents observés chez le Fou à pieds bleus des Galápagos. Qu'elles soient de source naturelle ou anthropique, les répercussions du déclin des capacités de reproduction et de la survie des individus attribuables à la sénescence sont désastreuses pour cette icône de la biodiversité et de l'écotourisme génétiquement distincte.

Key Words: Galápagos; population cycle; population decline; sardine-anchovy cycle; seabird conservation; Sulid

\section{INTRODUCTION}

The abundance of seabirds across the vast Pacific Ocean basin is thought to have declined by at least $99 \%$ over the past 3000 years, coincident with the spread of Polynesian humans (Steadman 2006). Human settlements on islands lead to habitat loss, hunting, and indirect effects of predatory and other invasive animals accompanying humans (Szabo et al. 2012), and these effects are thought to explain the local extinction of most seabird species on colonized islands (Steadman 2006). The seabird populations of the Galápagos Islands, in the far east of the basin and distant from source populations of Polynesians, depart from this pattern.
Paleontological data give no evidence of permanent human habitation before approximately 200 years ago (Latorre 1997), and also no evidence of local extinction of seabird species (Steadman 1986, Jiménez-Uzcátegui et al. 2006). However, some species show clear evidence of recent anthropogenic effects that reduced population size (Vargas et al. 2005, Jiménez-Uzcátegui et al. 2006, Anderson et al. 2008), while other species are too poorly studied to allow similar evaluations. With a seabird fauna with most or all of its original members present, evaluation of possible anthropogenic effects on observed population declines must be a conservation priority. 
Blue-footed Boobies (S. nebouxii) breed on Galápagos and on islands and headlands on the west coast of South and Central America and México. The demography and population biology of the Galápagos subspecies ( $S$. n. excisa) is poorly known. However, serial data from two former breeding sites in Galápagos (Daphne Major and Punta Cevallos [Española]) indicate an abrupt change in breeding activity in approximately 1997, from irregular but frequent breeding to essentially none until the present (Fig. 1). This pattern is consistent with anecdotal observations of long-term scientists and tour guides that adults are seen less frequently, and breeding sites are seldom occupied, in recent years (D. J. Anderson, unpublished data). If the chronically poor breeding affects the entire subspecies, then low recruitment should be reflected in a reduced population size. Population size has been estimated only once, by Nelson in the 1960s. He concluded that "the total Galápagos population must exceed 10,000 pairs and could be substantially more" (Nelson 1978:515). Our goals in this study were to evaluate, at the archipelago scale, the indication from two colonies of poor breeding, and to estimate the current size of the Galápagos population.

Fig. 1. Numbers of active nests of Blue-footed Boobies (Sula nebouxii excisa) at Punta Cevallos, Española (D. J. Anderson, unpubublished data) and Daphne Major (P. R. Grant and B. R. Grant, unpubublished data). Vertical line indicates March 1 1997, middle of the 1997-1998 El Niño Southern Oscillation event, and roughly the timing of declining sardine abundance in the Peruvian upwelling. Stars indicate the peak of a rapid increase in number of nests followed by a mass breeding failure in the subsequent four weeks.

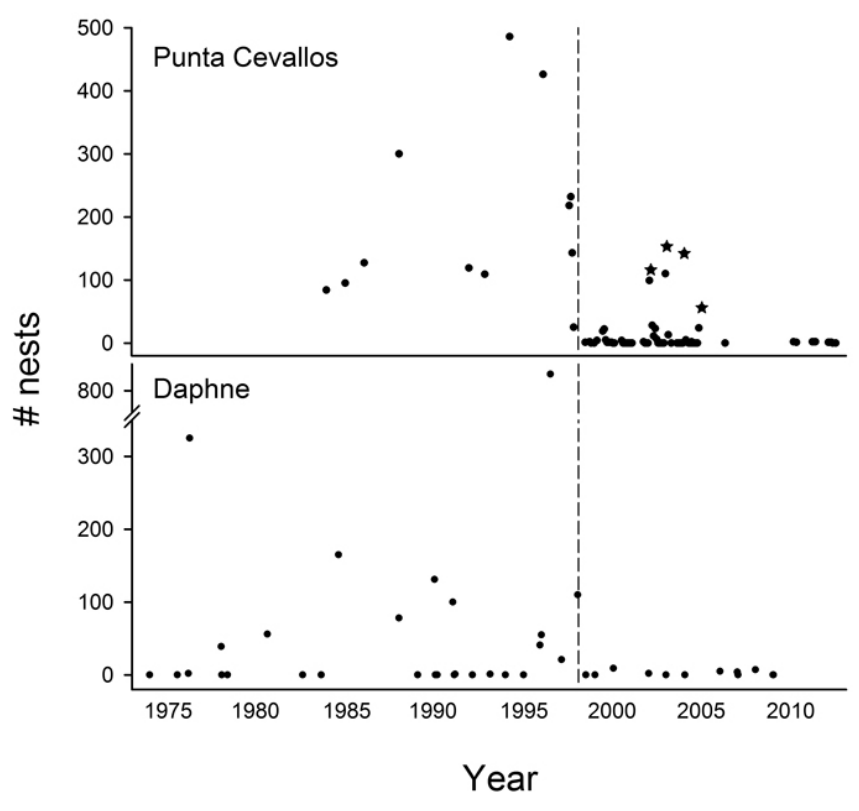

Terrestrial anthropogenic factors are unlikely to explain the pattern observed at the Daphne Major and Punta Cevallos colonies, because these two islands have no introduced predators and no permanent human presence. Furthermore, Nazca Boobies $(S$. granti), with similar terrestrial ecology, bred successfully at both sites before and after 1997 (D. J. Anderson, unpublished data; P. R. and B. R. Grant, unpublished data). These two islands (Fig. 2) differ in presence of their main native predator (Galápagos Hawks Buteo galapagoensis; Anderson 1991, Anderson and Hodum 1993) and nesting habitat occupied by Blue-footed Boobies (Townsend et al. 2002), yet their respective Blue-footed Booby populations ceased effective breeding simultaneously, suggesting a regional, marinebased cause, such as diet. Along the continental margin, $S . n$. nebouxii eats primarily schooling, lipid-rich (Schew and Ricklefs 1998, Müllers et al. 2009) members of two families: Clupeidae (sardines and herrings) and Engraulidae (anchovies; Zavalaga et al. 2007, Weimerskirch et al. 2009). Before 1997, Galápagos Bluefooted Boobies showed a similar specialization on a clupeid, the South American sardine (Sardinops sagax; Anderson 1989). In the only study after 1997, the most common items were also clupeids (Galápagos thread herring [Opisthonema berlangai] and European pilchard [Sardina pilchardus, almost certainly a misidentification of Sardinops sagax]; Cruz et al. 2012; L. L. Cruz, personal communication). Engraulids have not appeared in booby diets in Galápagos and are apparently rare in Galápagos (Anderson 1989, Grove and Lavenberg 1997, Cruz et al. 2012; D. J. Anderson, unpublished data). Sardines were common in the diet of Nazca Boobies at Punta Cevallos before 1997 (Anderson 1989), but virtually absent after 1997 (D. J. Anderson, unpublished data), suggesting a food-based cause of the simultaneous regional change in Blue-footed Booby population biology.

We evaluated several hypotheses regarding breeding, population size, and environmental factors influencing the Blue-footed Booby population in Galápagos: (1) breeding activity is less frequent than in the past; (2) the population of adults is smaller than in the past; and (3) diet characteristics, and consumption of clupeids in particular, influences breeding parameters including colony attendance, breeding attempts, egg and clutch size, and breeding success.

\section{METHODS}

\section{Breeding}

From May 2011-June 2013, we monitored breeding at 3- to 5-month intervals at 4 of the 6 historically largest breeding colonies of Bluefooted Boobies (Daphne Major, Cabo Douglas [Fernandina], Punta Vicente Roca [Isabela], and Seymour Norte), and one additional recently established colony (Playa de los Perros [Santa Cruz]; Fig. 2). A successful breeding attempt takes 5 to 6 months (42 d. of incubation, $\sim 100 \mathrm{~d}$. of nestling rearing, and at least $28 \mathrm{~d}$. of post-fledging feeding at the colony [Nelson 1978, Harris 1982]), so we were unlikely to have missed successful breeding. We visited each of these five "focal colonies" at night, when attendance is highest, recording the number of adults present (birds in juvenile plumage were never present), band numbers if visible, and the number of active nests with eggs and the number with nestlings. A sixth regularly large and active colony, Punta Suárez (Española), and two others (Punta Pitt [San Cristobal] and Punta Cormorant [Floreana]; Fig. 2) were selected as "nonfocal colonies" and were visited less frequently (three or four times each) than were focal colonies. Breeding was monitored when possible during these visits, with time of day varying (Table 1). The seventh historically large colony at Punta Cevallos, was known to be essentially unattended through our group's other research activities there. An additional, 
Fig. 2. Location of focal and nonfocal colonies, islands, and sections scanned per day during the coastal survey of June 2012.

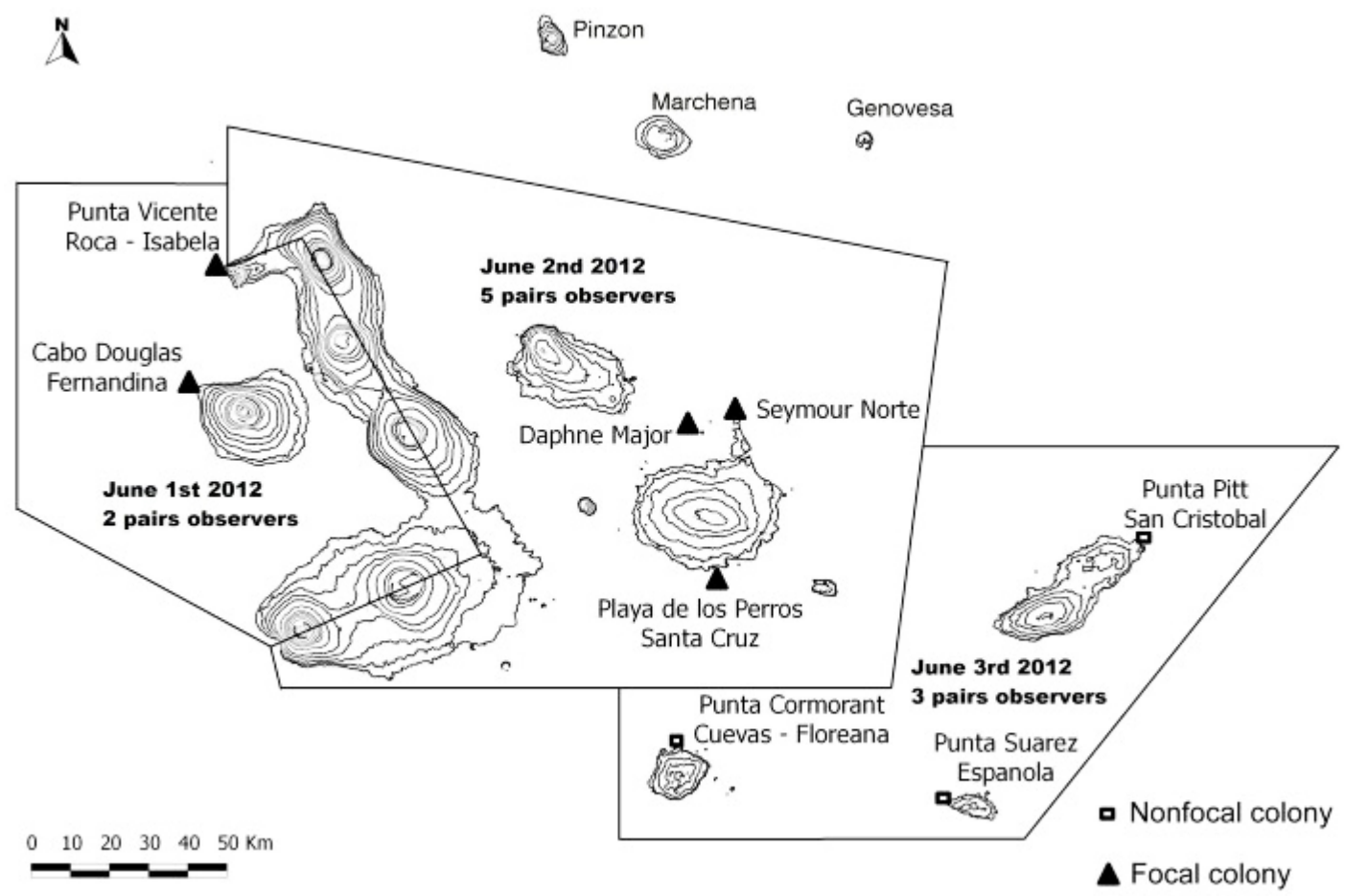

apparently newly established, nonfocal colony on Baltra was discovered in the second year of the study and entered the study in August 2012 as a nonfocal colony.

If diet explains any depression in breeding, this may be reflected in females' egg formation (clutch size and egg volume), as has been observed in this species (Dentressangle et al. 2008) and a congener (Anderson 1990, Clifford and Anderson 2001). Few eggs were available to us during this study, but in June 2012 we measured the length and breadth of 46 eggs from 26 clutches in the Playa de los Perros colony with calipers $(0.1 \mathrm{~mm}$ precision) and calculated egg volume as $\mathrm{V}=0.51^{*} \mathrm{LB}^{2}$ (Hoyt 1979), where $\mathrm{L}$ is the length and $\mathrm{B}$ the breadth of the egg. We compared these volumes with data collected during years of high attendance and successful breeding from Punta Cevallos (136 eggs in 1984 and 69 eggs in 1985). We used an information-theoretic approach to compare a cumulative logit model incorporating no effect of year (null model) on the response variable, clutch size, with a model incorporating the effect of year. We applied a similar approach to egg volume for eggs from 1 or 2 egg clutches, comparing a general linear model incorporating no effect of year on egg volume (null model) with a model incorporating the effect of year (year model), and we compared these models with a third model incorporating the effect of clutch size (clutch size model). These analyses were conducted using ProcLOGISTIC and ProcGLM, respectively, as implemented in SAS v. 9.3 (SAS Institute, Cary, North Carolina, USA).

\section{Population size}

We intended to use mark-resight methods (McClintock and White 2009) to estimate the sizes of the breeding and nonbreeding components of the Blue-footed Booby population and associated demographic parameters. We marked 879 adults with two leg bands (one numbered stainless steel band and one field-readable plastic band) at the five focal colonies. The majority of the birds were marked at the beginning of the study, in May 2011. We now recognize the large number of birds available for banding on this occasion as an anomaly, and attendance was dramatically lower in later visits to these colonies. The low attendance probably does not reflect a disruptive effect of our first visit, based on the reactions of Blue-footed Boobies to the same techniques at our Punta Cevallos site (1984-1997) and at the Playa de los Perros colony, which we visited frequently in 2011-2013. We resighted a total of only 245 banded birds in the five colonies, with these birds providing 328 total resights, during six resight sessions (i.e., resight rate averaged $6.2 \%$ per session) conducted at 3-5 month intervals until June 2013, due principally to low attendance and secondarily to some loss of plastic bands, rendering the mark-resight approach unworkable.

We made two surveys of the entire coastline of the islands south of the equator, including all of Isabela, as an alternative measure of population size. Blue-footed Boobies seldom visit the tropical, less productive waters (Houvenaghel 1978, Feldman 1986, Hayes and Baker 1989) around the five islands north of the Equator (Genovesa, Marchena, Pinta, Darwin, and Wolf), both 
Table 1. Schedule of visits and activities done on each colony. $\mathrm{M}_{\mathrm{N}}$ : monitoring breeding, presence of banded adults, diet sampling, at night; $\mathrm{M}_{\mathrm{D}}$ : monitoring breeding, presence of banded adults, diet sampling, at day; $\mathrm{C}$ : count of adults at day during coastal count across survey range.

\begin{tabular}{|c|c|c|c|c|c|c|c|c|c|}
\hline Colony site & $\begin{array}{l}\text { May } \\
2011 \\
\end{array}$ & $\begin{array}{c}\text { Jun } \\
2011 \\
\end{array}$ & $\begin{array}{l}\text { Aug } \\
2011 \\
\end{array}$ & $\begin{array}{c}\text { Dec 2011/ } \\
\text { Jan 2012 }\end{array}$ & $\begin{array}{l}\text { May } \\
2012 \\
\end{array}$ & $\begin{array}{c}\text { Jun } \\
2012 \\
\end{array}$ & $\begin{array}{l}\text { Aug } \\
2012 \\
\end{array}$ & $\begin{array}{c}\text { Dec 2012/ } \\
\text { Jan } 2013 \\
\end{array}$ & $\begin{array}{c}\text { Jun } \\
2013 \\
\end{array}$ \\
\hline \multicolumn{10}{|c|}{ FOCAL COLONIES } \\
\hline $\begin{array}{l}\text { Playa de los Perros } \\
\text { - Santa Cruz }\end{array}$ & $\mathrm{M}_{\mathrm{N}}$ & $\mathrm{C}$ & $\mathrm{M}_{\mathrm{N}}$ & $\mathrm{M}_{\mathrm{N}}$ & $\mathrm{M}_{\mathrm{N}}$ & $\mathrm{C}$ & $\mathrm{M}_{\mathrm{N}}$ & $\mathrm{M}_{\mathrm{N}}$ & $\mathrm{M}_{\mathrm{N}}$ \\
\hline Daphne Major & $\mathrm{M}_{\mathrm{N}}$ & $\mathrm{C}$ & $\mathrm{M}_{\mathrm{N}}$ & $\mathrm{M}_{\mathrm{N}}$ & $\mathrm{M}_{\mathrm{N}}$ & $\mathrm{C}$ & $\mathrm{M}_{\mathrm{N}}$ & $\mathrm{M}_{\mathrm{N}}$ & $\mathrm{M}_{\mathrm{N}}$ \\
\hline $\begin{array}{l}\text { Cabo Douglas } \\
\text { - Fernandina }\end{array}$ & $\mathrm{M}_{\mathrm{N}}$ & $\mathrm{C}$ & $\mathrm{M}_{\mathrm{N}}$ & $\mathrm{M}_{\mathrm{N}}^{\mathrm{N}}$ & $\mathrm{M}_{\mathrm{N}}^{\mathrm{N}}$ & $\mathrm{C}$ & $\mathrm{M}_{\mathrm{N}}^{\mathrm{N}}$ & $\mathrm{M}_{\mathrm{N}}^{\mathrm{N}}$ & $M_{N}^{N}$ \\
\hline $\begin{array}{l}\text { Pta. Vicente Roca } \\
\text { - Isabela }\end{array}$ & $\mathrm{M}_{\mathrm{N}}$ & $\mathrm{C}$ & $\mathrm{M}_{\mathrm{N}}$ & $\mathrm{M}_{\mathrm{N}}$ & $\mathrm{M}_{\mathrm{N}}$ & $\mathrm{C}$ & $\mathrm{M}_{\mathrm{N}}$ & $\mathrm{M}_{\mathrm{N}}$ & $\mathrm{M}_{\mathrm{N}}$ \\
\hline Seymour Norte & & $\mathrm{C}$ & $\mathrm{M}_{\mathrm{N}}$ & $\mathrm{M}_{\mathrm{N}}$ & $\mathrm{M}_{\mathrm{N}}$ & $\mathrm{C}$ & $\mathrm{M}_{\mathrm{N}}$ & $\mathrm{M}_{\mathrm{N}}$ & $\mathrm{M}_{\mathrm{N}}$ \\
\hline \multicolumn{10}{|c|}{ NONFOCAL COLONIES } \\
\hline $\begin{array}{l}\text { Punta Cormorant, Cuevas } \\
\text { - Floreana }\end{array}$ & & $\mathrm{M}_{\mathrm{D}}, \mathrm{C}$ & $\mathrm{M}_{\mathrm{D}}$ & & & $\mathrm{M}_{\mathrm{D}}, \mathrm{C}$ & & & $\mathrm{M}_{\mathrm{D}}$ \\
\hline $\begin{array}{l}\text { Punta Pitt } \\
\text { - San Cristóbal }\end{array}$ & & $\mathrm{M}_{\mathrm{D}}, \mathrm{C}$ & $\mathrm{M}_{\mathrm{N}}$ & & & $\mathrm{M}_{\mathrm{D}}, \mathrm{C}$ & & $\mathrm{M}_{\mathrm{N}}$ & $\mathrm{M}_{\mathrm{N}}$ \\
\hline $\begin{array}{l}\text { Punta Suárez } \\
\text { - Española }\end{array}$ & & & $\mathrm{M}_{\mathrm{N}}$ & & & $\mathrm{M}_{\mathrm{D}}, \mathrm{C}$ & & $\mathrm{M}_{\mathrm{N}}$ & $\mathrm{M}_{\mathrm{N}}$ \\
\hline $\begin{array}{l}\text { Punta Cevallos } \\
\text { - Española }\end{array}$ & & & $\mathrm{M}_{\mathrm{D}}$ & $\mathrm{M}_{\mathrm{D}}$ & & & $\mathrm{M}_{\mathrm{D}}$ & $\mathrm{M}_{\mathrm{D}}$ & $\mathrm{M}_{\mathrm{D}}$ \\
\hline $\begin{array}{l}\text { La Millonaria } \mathrm{M}_{\mathrm{D}} \mathrm{M}_{\mathrm{D}} \\
\text { - Baltra }\end{array}$ & & & & & & & $\mathrm{M}_{\mathrm{D}}$ & $M_{D}$ & $\mathrm{M}_{\mathrm{D}}$ \\
\hline
\end{tabular}

historically (Nelson 1978, Harris 1982) and during this study (D. J. Anderson, personal observation); this fact justifies the exclusion of these sites from the "survey range" comprising $1100 \mathrm{~km}$ of coastline of 14 islands and 20 islets. Almost no birds were breeding at the times of the two surveys, and we reasoned that nonbreeders would spend much of their time resting on sea cliffs based on our experience with this species, justifying the choice of a boat-based coastal survey. During the 2012 survey we also recorded birds sighted on the open ocean when the boats moved between islands as an additional test of the assumption. During both surveys, observers gave special attention to detecting new colonies, and counted historical and newly detected colonies on foot.

In the first survey, we made daytime counts in piecemeal fashion, covering the entire survey range in a boat at $1-\mathrm{m} / \mathrm{s}$ between 3 June and 7 August 2011, with a single observer (D. J. Anchundia) using binoculars 20-100 $\mathrm{m}$ from the coast to count birds. Each Bluefooted Booby perched on land or flying against the direction of the boat's movement was recorded, with adult or juvenile status, time of day, and latitude and longitude measured by a hand-held GPS unit.

In the second survey, on 1-3 June 2012, we used a dependent double observer protocol (Nichols et al. 2000). A "primary" observer indicated to a "secondary" observer each bird that was roosting on the cliff faces directly to the side of the boat as the boat traveled parallel to the island. Birds that were flying away from the island and toward the boat were also counted if they flew within $200 \mathrm{~m}$ of the boat. At the time of the detections, the secondary observer recorded these data and any additional birds that were detected only by the secondary observer. Observers travelled on a boat moving $2-8 \mathrm{~m} / \mathrm{s} 20-100 \mathrm{~m}$ from the coast, using binoculars to detect birds on land and flying against the direction of the boat's travel. In the single exception to this protocol, during the 2012 count in the northwest part of Santiago, the boat moved $>1 \mathrm{~km}$ from the coast for $19 \mathrm{~km}(1.7 \%$ of the total coastline surveyed) because of hazardous navigation, so the birds on land and over water near the coast were missed. Birds sighted were counted and binned into 30 min travel intervals ("stretches") by 2-5 pairs of observers, depending on the day, each pair on a separate boat covering a unique part of the coastline (Fig. 2). GPS locations were recorded at the start and end locations of each stretch. To minimize double-counting or missing a bird due to its movement between parts of the survey range, we conducted the survey over the smallest time period possible $(3 \mathrm{~d})$ given the availability of suitable boats. All pairs of observers working on a given day counted in the same area of the survey range, with the areas chosen to minimize the possibility of birds moving between the three daily count areas during the survey (Fig. 2). On 1 June, two observer pairs counted the western archipelago, reasoning that interchange between that region and the rest of the archipelago was rare. In particular, few birds cross the narrow Perry Isthmus in the middle of Isabela each day (Fig. 2; Anchundia 2013). On 2 June, 5 observer pairs counted eastern Isabela and the 8 islands and 15 islets in the central part of the survey range. On 3 June, three observer pairs counted the relatively isolated islands and islets in the east, southeast, and south of the archipelago (Fig. 2). The second survey differed from the first in time frame (compressed in 2012) and in number of simultaneous observers, enabling estimates of detection probability in 2012 , and it can be expected a priori to provide a more accurate estimate than the 2011 count. 
Data collected during these double-observer surveys resulted in individual encounter histories of " 10 " for birds that were detected by the primary observer and " 01 " for birds detected only by the secondary observer. We tabulated the number of birds with each type of encounter history for each stretch and treated each stretch as a separate group in our analyses. To estimate the probability of detection $(p)$, we used a Huggins closed captures model (Huggins 1989, 1991) as implemented in Program MARK (White and Burnham 1999), which uses information from the two observer types to calculate the maximum likelihood value of detection probability. We developed a set of four models reflecting four hypotheses for variation in $p$ where $p$ was estimated as (1) a common probability for all stretches combined (CONSTANT), (2) a common probability for all stretches counted by each of the six primary observers (OBSERVERS), (3) a common probability for all stretches around each island or geographically distinct section of very large islands (ISLANDS), and (4) a separate detection probability for all stretches (STRETCHES). We used an information-theoretic approach for model selection (Burnham and Anderson 2002, Anderson 2008) and present model-averaged estimates of population size, $\hat{N}$, for each island and for the entire archipelago as detailed below.

Birds in flight might fly near the coast, where they could be seen and recorded during our coastal surveys, or fly over the open ocean outside the visual range of our boat-based observers. To evaluate the visibility of birds flying during the coastal surveys, we deployed SIMA ${ }^{\circledR}$ GPS tags on a total of 34 nesting adults (20 females and 14 males) in focal colonies in: May and August 2011; May, August, and December 2012; and January 2013. At Playa de los Perros 25 units (on 15 females and 10 males) were deployed, at Daphne Major six units (on three females and three males), and at Cabo Douglas three units (on two females and one male). The tags were deployed at night and usually recovered during the following night. Previous radio tracking showed that Blue-footed Boobies foraged only during daylight hours and usually completed a foraging trip and returned to the nest during one daylight period (Anderson and Ricklefs 1987, 1992). The tags recorded the bird's position every 10 or $15 \mathrm{sec}$. They were enclosed in two layers of latex condom and attached to the underside of four tail feathers using water-resistant Tesa tape ${ }^{\circledR}$; total weight of tag and packaging was $27 \mathrm{~g}$, representing $2.1 \%$ and $1.5 \%$ of mean adult weight of males and females, respectively (Nelson 2005). The "generate near table" tool of ArcGIS ${ }^{\circledR} 10.0$ was used to determine the proportion of locations within $200 \mathrm{~m}$ of a coastline.

\section{Diet}

Induced and spontaneous regurgitations were collected during late afternoon or at night. For induced regurgitation, the bird was captured in the colony and its head was enclosed in a cloth weighing bag for $30 \mathrm{sec}$, with the head and body of the bird oriented downward. Prey were identified, weighed, and measured for fork length. Spontaneous regurgitation by a bird not in the hand was treated similarly. Fork lengths were converted to weights using taxon-specific equations (FishBase, http://www.fishbase. org). We examined a set of five models in a logit analysis (ProcGENMOD; SAS v. 9.3) comparing the representation of clupeids in the diet across colonies in different regions of the archipelago and between years. In this analysis, prey category $(1=$ clupeid, $0=$ nonclupeid) was the response variable and we examined models with single, additive, and interactive effects of the categorical predictor variables year and region (west, central, or southeast).

We evaluated the associations between a metric of Blue-footed Booby foraging (PROPENSITY) and breeding motivation using logistic regression as implemented in ProcLOGISTIC in SAS v. 9.3. The response variable, the birds' motivation to breed (MOTIVATION), was scored "yes" for a given colony (both focal and nonfocal) on a given visit if the estimated number of pairs attending a colony exceeded $5 \%$ of the historical maximum number of nests for that colony, and "no" for a given colony and visit if $5 \%$ or fewer of historical nest numbers were observed. The very low attendance at colonies during this study required such a low value for this criterion to yield some "yes" scores. Birds were sexed using the sexually dimorphic iris (Nelson 1978). The ratio of males to females in this sample was applied to those individuals that could not be seen clearly. The number of the least numerous sex was doubled to give an estimate of the total number of breeding pairs, which was compared to historic breeding numbers. In many cases, the adults were present but had not laid eggs; we considered them to be demonstrating "breeding motivation" by attending the colony.

We were interested in the relative importance of the foraging metric, PROPENSITY, and the temporal covariates YEAR and MONTH (a nominal variable approximating seasonal effects) in predicting the probability of breeding MOTIVATION, where we modeled the probability of a "yes" response. PROPENSITY is a measure of the propensity of birds to regurgitate when handled, which we calculated as the proportion of birds that regurgitated after capture and confinement in a weighing bag for $30 \mathrm{sec}$, providing an index of the general availability of prey items. We developed a set of eight logistic regression models, including an intercept-only model, and all single and additive combinations of the variables of interest, and used an information-theoretic approach for model selection and to draw inferences from this model set.

\section{Model selection and inference}

For analyses of clutch size, egg volume, population size, and foraging metrics, we used an information-theoretic approach (Burnham and Anderson 2002, Anderson 2008) to rank models and draw inferences from a set of models. Model selection was based on Akaike's Information Criterion values corrected for small sample sizes (AICc). For the three models of egg size (no effect, year effect, clutch size effect), we computed the residual sum of squares of each model and calculated AICc following the equation:

$$
\mathrm{AICc}=N * \ln (\mathrm{RSS} / N)+2 K+(2 K(K+1) / N-K-1),
$$

where $N$ is sample size and $K$ indicates the number of parameters (Burnham and Anderson 2002, Anderson 2008). The three models were ranked based on their AICc values, with the model with the lowest AICc considered to be the best model. We also report AICc differences $\left(\Delta_{i}\right.$; the difference between each model, $i$, and the top-ranking model) and Akaike weights ( $w_{i}$; estimates of the probability that model $i$ is the best model given the data and the model set) for each model. Finally, we calculated the ratio of the model probabilities $\left(w_{i}\right)$ to provide a measure of the strength of evidence for one model over the other (i.e., evidence ratios). 
Table 2. Blue-footed Booby (Sula nebouxii excisa) breeding activity at colonies in Galápagos in 2011, 2012, and 2013 in relation to historical maxima.

\begin{tabular}{|c|c|c|c|c|}
\hline Colony site & $\begin{array}{l}\text { Historical maximum } \\
\text { \# nests }\end{array}$ & $\begin{array}{c}\text { Maximum \# nests } \\
\text { in } 2011 \\
\end{array}$ & $\begin{array}{l}\text { Maximum \# nests } \\
\text { in } 2012 \\
\end{array}$ & $\begin{array}{c}\text { Maximum \# nests } \\
\text { in } 2013 \\
\end{array}$ \\
\hline Daphne Major & 836 & $4(<1 \%)$ & $4(<1 \%)$ & $3(<1 \%)$ \\
\hline Seymour Norte & 965 & $16(2 \%)$ & $62(6 \%)$ & $59(6 \%)$ \\
\hline $\begin{array}{l}\text { Playa de los Perros } \\
\text { - Santa Cruz }\end{array}$ & No data & 73 & 62 & 124 \\
\hline $\begin{array}{l}\text { Cabo Douglas } \\
\text { - Fernandina }\end{array}$ & 1467 & $1(<1 \%)$ & $1(<1 \%)$ & 0 \\
\hline $\begin{array}{l}\text { Punta Vicente Roca } \\
\text { - Isabela }\end{array}$ & 1800 & $67(4 \%)$ & 0 & $15(1 \%)$ \\
\hline $\begin{array}{l}\text { P. Cormorant and Cuevas } \\
\text { - Floreana }\end{array}$ & 134 & $3(2 \%)$ & $6(4 \%)$ & $20(15 \%)$ \\
\hline $\begin{array}{l}\text { Punta Pitt } \\
\text { - San Cristóbal }\end{array}$ & No data & 2 & 3 & 8 \\
\hline $\begin{array}{l}\text { Punta Suárez } \\
\text { - Española }\end{array}$ & 256 & $29(11 \%)$ & $11(4 \%)$ & $26(10 \%)$ \\
\hline $\begin{array}{l}\text { La millonaria } \\
\text { - Baltra }\end{array}$ & New colony & No data & 49 & 94 \\
\hline
\end{tabular}

Similarly, we used AICc to rank models and draw inferences about detection probability $(p)$ in the process of estimating abundance. Using the Huggins closed captures approach, population size, N, is conditioned out of the likelihood, so estimates of population size, $\hat{N}$, were derived parameters from the models of $p$. To account for model selection uncertainty among the set of models of $p$, here we present model-averaged $\hat{N}$ values and associated confidence intervals (Burnham et al. 1987). We also used AICc, $\triangle \mathrm{AICc}$, and $w_{i}$ values for ranking and drawing inferences from the model set examining the effect of foraging and season effects on breeding motivation. For this analysis, we also report relative importance values (variable weights) for each predictor variable, expressed as the sum of the Akaike weights for the models in which a particular variable appeared (Burnham and Anderson 2002).

\section{Distribution in the Eastern Tropical Pacific}

Blue-footed Boobies display an easily recognized juvenile plumage until age 2-3 years (Nelson 1978). Infrequent observation of Blue-footed Boobies in juvenile plumage could indicate low breeding success over the previous 2-3 years, or temporary emigration of juveniles from the range of the adults. To evaluate the distribution of birds in juvenile plumage, we used data from ship-based surveys across the eastern tropical Pacific (ETP) collected between 1988-2006 (L. Ballance and R. Pitman, unpublished data).

\section{RESULTS}

\section{Breeding}

Breeding activity was much lower than historical maximum figures, with all monitored colonies containing $<15 \%$ of the historical maximum on most visits (Table 2; see also Appendix 3 of Anchundia 2013). Summing across all monitored sites, the largest number of simultaneous nests observed (349) represents 698 breeding birds, only $10.9 \%$ of the population size estimate of
6423 adults. Three previously unknown breeding sites were identified during the study: on Baltra with approximately 49 nesting pairs in 2012 and 94 nesting pairs in 2013 (Table 2); on the south coast of Fernandina west of Punta Mangle, with approximately 75 adults present and an unknown number of nests; and on the south coast of Isabela (Los Tuneles) with 9 nesting pairs in 2013. The formerly large colony at Punta Cevallos (489 nests in 1994; Townsend et al. 2002) was not monitored as part of this study, but was checked frequently as part of our ongoing research there; no more than three nests were ever present there during this study.

Most breeding attempts did not include a nestling during our visits. Most clutches failed without producing a nestling: on visits after one in which nests with eggs were recorded, few or no nestlings or fledglings, either living or dead, were found, although incubating adults may have been present, possibly on new clutches. In the focal colonies in 2011, the total number of fledglings was 26 ( 9 at Playa de los Perros, 9 at Cabo Douglas, and 8 at Seymour), and in 2012, 59 offspring fledged (18 at Playa de los Perros, 12 at Seymour, 24 at Baltra, 1 at Daphne Major, and 5 at Punta Suárez). December and January were the only months in the 3-year study in which we observed large offspring and fledglings, with the exception of the newly established Baltra colony, in which 24 fledglings were present in August 2012.

Clutch sizes in 2012 did not differ from those in 1984 and 1985: 2 eggs was the most common clutch size in all 3 years and the null model was 3.33 times more likely than a model with the year effect. However, the mean volume of eggs in 2012 exceeded that in earlier years $\left(\right.$ mean $_{1984}=56.3 \mathrm{cc}, \mathrm{SE}=0.44 ;$ mean $_{1985}=56.5 \mathrm{cc}, \mathrm{SE}=$ $0.70 ;$ mean $\left._{2012}=61.1 \mathrm{cc}, \mathrm{SE}=1.14\right)$; the model incorporating an effect of year on egg volumes carried most of the Akaike weight (0.73), was $3 \times 10^{6}$ times more likely than the model with no effect of year on egg volume, and was 2.7 times more likely than the model with a clutch size effect. 


\section{Population size}

In the 2011 coastal survey, 7379 individuals were counted, of which two $(0.03 \%$ of the total count) were in juvenile plumage. That survey was conducted over an 11-week period by a single observer, with significant potential for missing or doublecounting individuals. In the 3-d 2012 coastal survey, detection probabilities were high and varied by island and stretch. The topranked ISLANDS model of detection probability carried an AICc weight of 0.68 (Table 3), and estimates of detection ranged from a low of 0.907 (95\% CI: 0.843 - 0.947) for Española to 0.994 (95\% CI: 0.982 - 0.998) on the southern portion of Isabela (Appendix Table A1.1). The model in which detection varied by stretch (STRETCHES) carried an AICc weight of 0.315 while the other two models carried no weight. The model-averaged estimate of population size ( $\hat{N}$ ) for the entire Archipelago from the 2012 survey was 6423 (95\%CI: 6420 - 6431; Table 4).

Table 3. Candidate model set and ranking of models examining variation in the probability of detection of Blue-footed Boobies (Sula nebouxii excisa) during coastal surveys, June 2012. Models were evaluated with detection probabilities varying by island, varying among 30-min stretches, varying among observers, and remaining constant. The number of parameters, deviance, $-2 \mathrm{log}$ likelihood $(-2 \log (\mathrm{L}))$, small sample size-corrected AIC values (AICc), AICc differences ( $\triangle \mathrm{AICc}$ ), Akaike weights (wi) are reported for the four models of detection.

\begin{tabular}{lccccc}
\hline \hline Model & $\mathrm{K}$ & $-2 \log (\mathrm{L})$ & $\mathrm{AICc}$ & $\Delta \mathrm{AICc}$ & $w_{i}$ \\
\hline ISLAND & 17 & 1346.08 & 1380.13 & 0.00 & 0.69 \\
STRETCHES & 131 & 1116.97 & 1381.69 & 1.56 & 0.32 \\
OBSERVERS & 5 & 1392.91 & 1402.92 & 22.79 & 0.00 \\
CONSTANT & 1 & 1408.38 & 1410.38 & 30.25 & 0.00 \\
& & & & & \\
\hline
\end{tabular}

These estimates apply to the portion of the population visible during daylight from boats within $100 \mathrm{~m}$ of the coast, and exclude birds away from the coast. Four lines of evidence indicate that few birds were outside the visual range of observers on the survey boats: (1) birds with GPS tags spent most of their foraging time within $200 \mathrm{~m}$ of an island's coast, well within visual range; (2) during boat travel between islands during the 2012 survey Bluefooted Boobies were sighted at a rate of only 2 birds $/ 30 \mathrm{~min}$ compared to an average of $48 \mathrm{birds} / 30 \mathrm{~min}$ on the coast; (3) $~ 85 \%$ of birds sighted during the 2012 survey were resting on land and not on the move; and (4) $>90 \%$ of the birds seen flying during the 2012 survey were moving parallel to the coast, rather than to or from the open ocean.

\section{Movements}

Most of the tagged birds did not travel far from the coast: $81.9 \%$ of the GPS points during foraging trips were within $200 \mathrm{~m}$ of an island coastline. Foraging birds did not cross land except to fly directly from their nests to the water and back, so most flight time was over coastal water. Considering all GPS points, including those stationary on land, only $8.8 \%$ were more than $200 \mathrm{~m}$ from a coastline. Many of the foraging sites identified by kernel analysis were within $200 \mathrm{~m}$ of an island coast (mean $=44.5 \mathrm{~m}$ [S.D. $=$
53.5]). Birds at sea travelled up to $68 \mathrm{~km}($ median $=11.2 \mathrm{~km})$ from their breeding colony, on trips that ranged in duration from $0.4-18.1 \mathrm{~h}($ median $=2.3 \mathrm{~h})$.

Table 4. Population size estimates $(\hat{N})$ by island, standard errors (SE) and lower (LCI) and upper (UCI) 95\% confidence intervals for Blue-footed boobies (Sula nebouxii excisa) surveyed in the Galápagos Archipelago in June 2012. Estimates are derived, model-averaged estimates from the models of detection probability using a Huggins closed captures approach.

\begin{tabular}{lrrrr}
\hline \hline Island & $\hat{N}$ & SE & LCI & UCI \\
\hline Española & 166 & 2 & 165 & 172 \\
San Cristóbal & 410 & 0 & 410 & 412 \\
Floreana \& Islets & 394 & 1 & 393 & 398 \\
Santa Fe & 117 & 0 & 117 & 118 \\
Santa Cruz & 1026 & 1 & 1025 & 1031 \\
Pinzon & 73 & 0 & 73 & 73 \\
Rábida & 15 & 0 & 15 & 15 \\
Daphne Minor & 94 & 0 & 94 & 94 \\
Daphne Major & 77 & 0 & 77 & 77 \\
Seymour & 90 & 0 & 90 & 92 \\
Baltra & 157 & 0 & 157 & 159 \\
Santiago & 856 & 0 & 856 & 858 \\
W. Isabela & 1322 & 1 & 1322 & 1326 \\
E. Isabela & 466 & 1 & 465 & 469 \\
S. Isabela & 529 & 0 & 529 & 530 \\
Fernandina & 631 & 1 & 630 & 634 \\
Archipelago & 6423 & 3 & 6420 & 6431 \\
& & & & \\
\hline
\end{tabular}

Birds from Playa de los Perros foraged at a variety of sites, including coastal spots like the Canal de Itabaca between Santa Cruz and Baltra and the coast of Santa Fé, and more pelagic locations to the south of the breeding colony. In contrast, most of the birds from Daphne Major foraged close to the coasts of nearby Santa Cruz, Seymour, Baltra, and Daphne Minor. The three birds from Cabo Douglas all foraged within 2.1-4.7 km of the colony and within sight of the coast in shallower water to the east of the colony and not in much deeper water to the west, north, and south.

Of the 879 birds banded in breeding colonies, 245 were resighted during later night visits to colonies. Seven of these resights (0.029) placed the bird in a different breeding colony from the banding site (details in Anchundia 2013), indicating high breeding site fidelity.

\section{Diet}

We collected a total of 218 regurgitations, containing 1284 prey items in total, from 8 colonies. Because of partial digestion, 35 items $(2.7 \%)$ were not intact and could not be measured, and 6 items $(0.5 \%)$ could not be assigned to species. Clupeids were the most common item in the samples, representing $80.2 \%$ of all items and $50.4 \%$ of the total weight (Fig. 3). The fork length of the fish ranged from $3 \mathrm{~cm}$ to $35 \mathrm{~cm}$, with a mean of $6.8 \mathrm{~cm}(\mathrm{SD}=3.2)$. 
Table 5. Candidate model set and ranking of models representing associations between the foraging metric PROPENSITY and breeding motivation as well as temporal covariates MONTH and YEAR for Blue-footed Booby (Sula nebouxii excisa) nesting sites studied in Galápagos, Ecuador. The number of parameters (K) in each model, the $-2 \log$ likelihoods $(-2 \log (\mathrm{L}))$, and small sample size-corrected AIC values (AICc) are shown. The models are ranked by their AICc differences ( $\mathrm{AICc}$ ) relative to the best model in the set and the Akaike weights (wi) reflect the probability that a model is the best model in the set.

\begin{tabular}{lccccc}
\hline \hline Model & $\mathrm{K}$ & $-2 \log (\mathrm{L})$ & $\mathrm{AICc}$ & \multicolumn{1}{c}{$\Delta \mathrm{AICc}$} & $w_{i}$ \\
\hline MONTH + PROPENSITY & 4 & 43.14 & 52.25 & 0.00 & 0.56 \\
MONTH & 3 & 46.79 & 53.44 & 1.18 & 0.31 \\
YEAR + MONTH + PROPENSITY & 6 & 42.51 & 56.99 & 4.73 & 0.05 \\
YEAR + MONTH & 5 & 46.30 & 58.01 & 5.76 & 0.03 \\
INTERCEPT-ONLY & 1 & 56.81 & 58.92 & 6.66 & 0.02 \\
PROPENSITY & 2 & 54.75 & 59.07 & 6.82 & 0.02 \\
YEAR + PROPENSITY & 4 & 51.94 & 61.05 & 8.79 & 0.01 \\
YEAR & 3 & 54.83 & 61.48 & 9.23 & 0.01 \\
\hline
\end{tabular}

The colonies visited fell into three clusters based on oceanographic habitat: the western colonies of Fernandina and Punta Vicente Roca, adjacent to the productive upwelling of the Equatorial Countercurrent with much lower sea surface temperature (SST) than elsewhere in the archipelago (Ruiz and Wolf 2011); the central colonies of Daphne Major, Seymour, Baltra, and Santa Cruz, adjacent to a complex merging of currents and a mosaic of SST and productivity (Witman et al. 2010); and the southeastern colonies on San Cristóbal, Española, and Floreana, in a generally less complex and less productive marine habitat. The diet composition in these regions varied, with clupeids much more common and occurring more regularly in the central cluster during this study, particularly in 2012. Clupeids were $68 \%$ of the prey items in the central colonies, but 28 and $29 \%$ of those in the western and southeastern colonies, respectively (Appendix Table A1.2). The top-ranked model in the logit analysis was that incorporating a year by region interaction; the probability that a prey item was a clupeid was higher in the central and south regions in 2011, was higher in 2012 in the central region, and was low to zero in the west across the 2 years. This model carried nearly all of the Akaike weight $\left(w_{i}=0.9999\right)$.

\section{Predictors of breeding motivation}

The breeding motivation response was related to the season of sampling, with the effect of MONTH negatively related to breeding motivation in December (breeding motivation was low in December), but not in May or August (for these months, the effect was positive but the $95 \%$ confidence intervals overlapped $0)$. MONTH was included in all of the top models in our logistic regression model set (Table 5) and had a high relative importance value (i.e., MONTH accounted for $94 \%$ of the cumulative Akaike weight in the model set, cumulative Akaike weight $=0.94$ ). This effect was followed in importance by PROPENSITY, which carried a cumulative Akaike weight of 0.635 and was in the topranked model with MONTH. Finally, YEAR was relatively unimportant, appearing in highly ranked models only when accompanied by MONTH or PROPENSITY and with a cumulative Akaike weight of 0.096 .
Fig. 3. Proportion of each fish taxon in regurgitation samples, by number of items, $\mathrm{n}=1721$ and weight, total $=18,117 \mathrm{~g}$. The two species at the top are Clupeid. Not shown: Panamic sergeant major (Abudefduf troschelii), three items, $99 \mathrm{~g}$; Carangids (Caranx spp.), three items, $20 \mathrm{~g}$; Cortez rainbow (Thalassoma ucasanum), five items, $38 \mathrm{~g}$; squid Decapodiformes, one item, $<1 \mathrm{~g}$.

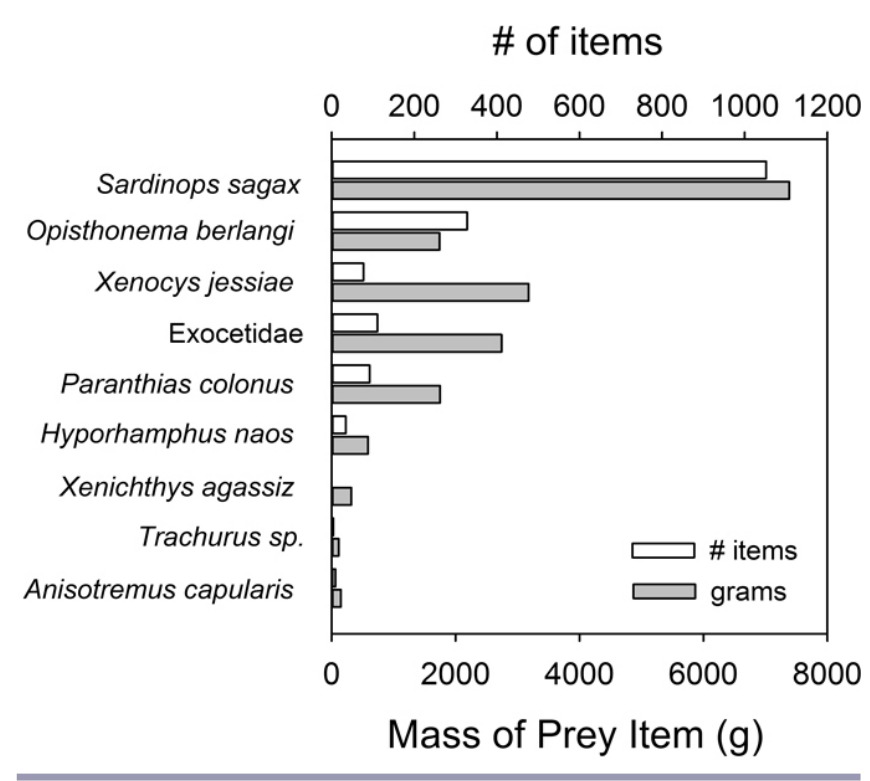

\section{Distribution of Blue-footed Boobies in the ETP}

In December 2010, 6 months prior to the start of this study, we observed that the Playa de los Perros colony contained 225 fledglings, suggesting good conditions for chick-rearing at that time for this colony. However, in the coastal survey done in June 2011 we observed only 2 juveniles, and in the coastal survey of 2012 we observed only 75 . Did most of these juveniles die, or did 
they move away from the archipelago? Ship-based surveys across the ETP between 1988-2006 show many juveniles near the large breeding colonies on the northwest coast of South America, mostly near La Plata Island (Ecuador), Lobos de Tierra Island (Perú), and the Gulf of California, and very few juveniles away from land (Fig. $4)$.

Fig. 4. Distribution of juvenile Blue-footed Boobies (Sula nebouxii excisa) in the eastern tropical Pacific from ship-based surveys, 1988-2006.

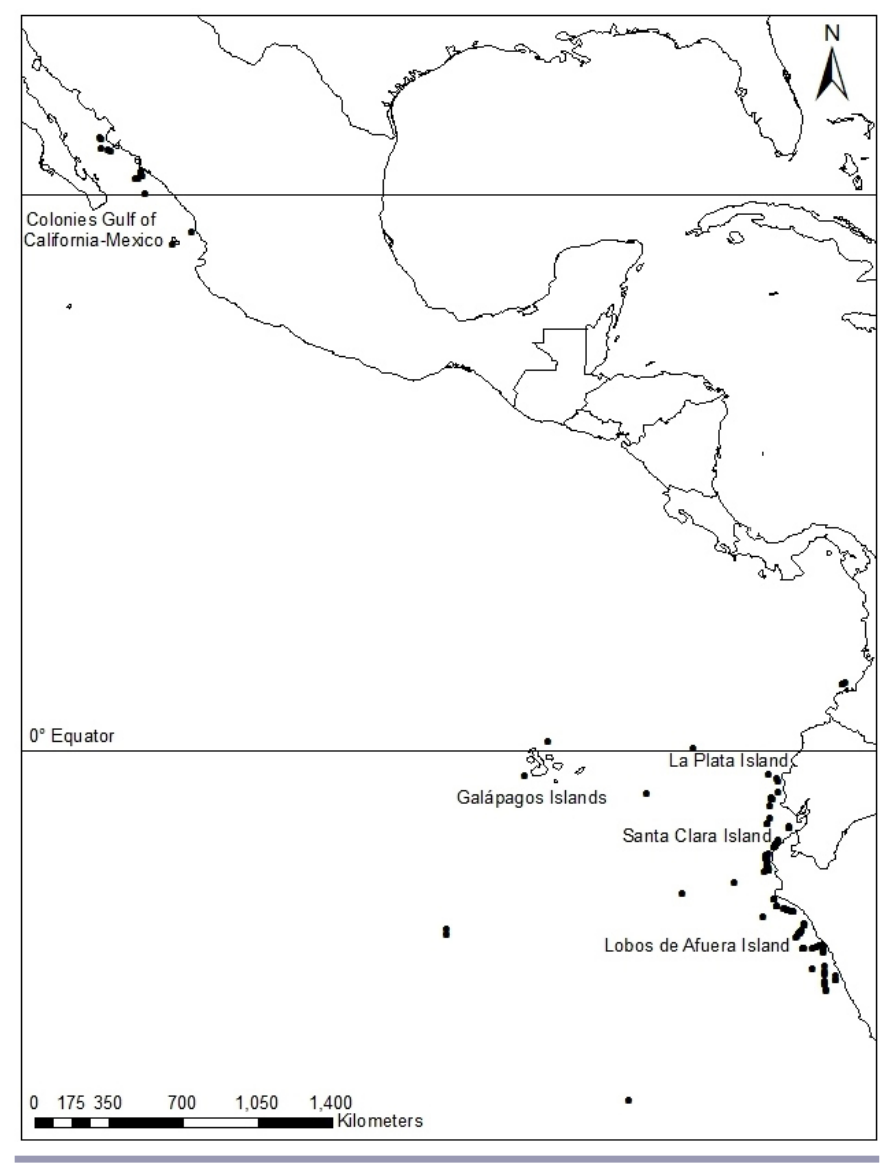

\section{DISCUSSION}

Our results indicate that Galápagos Blue-footed Boobies have attempted to breed very little between August 2011 and June 2013. During this period no more than $10.9 \%$ of the adult population had an active nest at any one time, and only 134 fledglings were noted during this time. During two comprehensive coastal surveys we recorded a total of only 77 birds in juvenile plumage (maintained until age 2-3 years; Nelson 1978) compared to an adult population estimated as 6423 birds. We sighted only 2 juveniles across the archipelago between May and August 2011, indicating that essentially no successful breeding occurred in the previous 2 years. We discount the possibility of temporary emigration of juveniles, based on the distribution of juveniles at sea (Fig. 4) and the abundance of juveniles in both coastal areas and between islands before 1998 (D. J. Anderson, personal observation). The simplest interpretation of these results is of chronic poor breeding over the
4 years 2009-2012. Noting the similar situation on Española and Daphne since 1997 (Fig. 1), this chronic breeding failure may span a total of 16 years.

Our population size estimate from 2012 indicates that the adult population numbers approximately 6423 , less than $1 / 3$ of the only other estimate, from the 1960s. Questions can be raised about the methodology used for both estimates. Little information is available regarding the first estimate, and we do not know the technique used. Nelson (1978:515) provided this estimate, first reviewing early counts from some islands (1000 pairs on Daphne Major and 500-800 pairs on Española's Punta Suárez) and then apparently summarizing unpublished data and impressions from his own year in Galápagos (mostly in 1964) on a few islands and also from the more extensive experience of others, such as M. P. Harris, in the 1960s: "the total Galapagos [sic] population must exceed 10000 pairs and could be substantially more...". Without further clarification of methods and measurement error, little more can be said about this estimate except that it was made by careful scientists and probably represents at least 20,000 adults. If Nelson's estimate omitted temporarily nonbreeding adults (i.e., young adults that have not yet bred or adults skipping breeding) then 20,000 is an underestimate of total population size.

Regarding the 2012 estimate, it is based almost exclusively on counts of birds resting on the coast or coastal waters or flying within sight of the coast during a short survey. The detection probability of birds using this method was high for birds within sight of the boat, and several lines of evidence indicate that the proportion of birds missed at sea was low: most birds sighted were on land; most birds sighted flying were moving parallel to the coast; GPS tracking places most flying time within $200 \mathrm{~m}$ of some coast, allowing the deduction that $3.2 \%$ of birds were out of visual range of boats surveying the coast region; and little breeding was occurring at the time of the survey, so few to no birds were at nest sites not visible from the water. Taking the 1960s estimate and our new estimate at their face values, a trend of a population decline is indicated, with the current population approximately 33\% of Nelson's (1978) estimate of the size of the 1960s population. Acknowledging significant uncertainty in the actual values, especially for the $1960 \mathrm{~s}$ estimate, we conclude that the population has declined in size by at least $50 \%$ since the $1960 \mathrm{~s}$, and probably by more than $50 \%$.

Birth, death, immigration, and emigration are the demographic processes affecting population size. Considering birth, very few adults attempted to breed, and virtually none succeeded during our study. Even colony attendance at the former colonies in the whole archipelago was very low during this study compared to historical attendance, including historical maxima (Table 2). We searched for potential new colonies during the two surveys and found only one small colony on Fernandina. Another colony was discovered a month after the June 2012 survey, on Baltra, but both colonies are small compared with the size of past colonies. With poor breeding, the adult population size will continue to shrink until at least 2015, when new adults would recruit from successful breeding (if any) after our study ended. Assuming that roughly $10 \%$ of adults die each year (Oro et al. 2010), population growth would require recruitment that exceeds $10 \%$ of the adult population size, which is apparently not the case currently.

Time series data from Punta Cevallos and from Daphne Major (Fig. 1) suggest that the chronic poor breeding, and thus the decline in population size, began during the 1997-1998 El Niño Southern 
Oscillation event. A simple model of population shrinkage is broadly in agreement. Assuming constant annual adult mortality of 0.10 , an initial adult population size of 20,000, and a continuous series of years ending in 2012 with no successful breeding, the hypothetical chronic breeding failure would have begun in 2001,11 years earlier $\left(20,000 * 0.90^{11}=6276\right.$; a larger starting population would bring this date even closer to 1997. Since 1997 the formerly large and regularly active Blue-footed Booby colony at Punta Cevallos has been virtually vacant, and on Daphne Major few adults currently attend in a small part of the main crater, whereas in the past the main crater and a side crater were covered by up to 1600 Blue-footed Boobies at times (Fig. 1). Now vegetation covers much of the past breeding site. Neither of these islands supports a possible introduced predator, and no evidence of the effects of disease has been noted among breeders or nonbreeders at either site. These two colonies are in separate oceanographic habitat regions of the archipelago, but exhibit similar breeding histories, suggesting the possibility that breeding has been poor across the archipelago since 1997 and depends little on spatial habitat variation. If so, then the age structure of the current population must be strongly biased toward elderly individuals; if Blue-footed Boobies show actuarial senescence, as Nazca Boobies do (Anderson and Apanius 2003) in addition to reproductive senescence (Velando et al. 2006), then the birth and death processes leading to smaller population size can be expected to accelerate in the future.

Individuals may be added to or subtracted from the Blue-footed Booby population via immigration or emigration, respectively, but these processes seem unlikely to be important in this species. The genetic differentiation and very low gene flow of $S$. n. excisa in Galápagos and S. n. nebouxii on the continental coast (Taylor et al. 2011) imply little movement between Galápagos and the Americas. Adults studied with electronic tags foraged within 100 $\mathrm{km}$ of land but rest at night on land (Nelson 1978, Anderson and Ricklefs 1987, this study), limiting their ability to move widely on the open ocean or transfer to the continental shelf of the Americas. Similarly, temporary movement of juveniles away from Galápagos is not indicated by ship-based surveys, which instead show concentrations of juveniles near breeding colonies (Fig. 4). In contrast to the current situation, in the 1980s and early 1990s, when breeding conditions were better, birds in juvenile plumage were seen regularly resting on sea cliffs and flying along the coast throughout Galápagos (D. J. Anderson, personal observation). Considering these circumstances, we conclude that the 225 juveniles produced in December 2010 did not move outside the survey range, and instead died before our coastal surveys. If so, then breeding and survival are apparently the most important demographic processes affecting population size in this system. Why are the birds not breeding, perhaps since 1997 ?

Two lines of evidence implicate diet. Considering long-term data from Punta Cevallos, Blue-footed Boobies foraged mostly on sardines, similar to Nazca Boobies (Anderson 1989), until 1997 (D. J. Anderson, unpublished data). After 1997, sardines disappeared from the Nazca Booby diet, but Nazca Boobies continued breeding by switching to other prey (D. J. Anderson, unpublished data). In contrast, Blue-footed Boobies abandoned this colony (Fig. 1). Data from Galápagos sea lions (Zalophus wollebaeki) suggest that sardines have become less available throughout the archipelago on approximately the same schedule as that of Punta Cevallos: they foraged mostly on sardines during the 1980s (Dellinger and Trillmich 1999), but more recently (2008-2009) sardines were completely absent from their diet (PáezRosas and Aurioles-Gamboa 2010). Diet samples taken during our study suggest that the central archipelago has a more regular availability of sardines currently than the other regions, and relatively more current breeding attempts have been observed on these islands. These data implicate clupeid availability in both initiation and success of breeding.

Consistent with this interpretation are the results of our logistic regression analysis suggesting that the season (measured as the month of our sampling) and propensity of a bird to regurgitate predict breeding motivation. We used PROPENSITY as a metric of foraging success, reasoning that a successful forager will readily regurgitate fish prey and because a prey-only metric (e.g., proportion of clupeids in prey samples) requires regurgitation before we can measure it; our metric approximates the feeding conditions a breeding adult experiences and upon which it bases breeding decisions. Nonetheless, the final explanation is probably more complex than our analysis suggests: PROPENSITY was relatively less important than the timing of our sampling; diet samples were taken on 1 or $2 \mathrm{~d}$ per 4 months, and this coarsegrain sampling may be unduly influenced by day-to-day variation in prey availability; and we used a criterion of $5 \%$ of the historical maximum for the breeding motivation response variable, which may be too lax to indicate breeding motivation reliably.

Noting the almost complete disappearance of the 225 fledglings observed in December 2010, we offer an additional, alternative interpretation of food availability and breeding: that clupeid availability is critical for recently independent young, and not necessarily for egg-formation and parental care. Under this hypothesis, parents should initiate breeding when the probability is high of clupeid availability five months in the future. When parents time reproduction in this way, their offspring can better avoid the typically high mortality of recently independent juveniles (Maness and Anderson 2013) by foraging on higher quality prey. When Blue-footed Boobies did attempt to breed during this study, their clutch sizes were similar to those from the 1980 s, and egg volumes were actually larger, indicating favorable current conditions. However, few birds attempted to breed, and most that initiated then failed. We speculate that parents were assessing the variable clupeid availability as insufficient to support independent juveniles several months in the future and so did not initiate, or initiated and then quickly abandoned the attempt. In contrast, we suspect that before 1997 sardines were available consistently in space and time, facilitating breeding motivation and later juvenile survival. Under this hypothesis, current diet characteristics are not expected to predict breeding motivation well in Blue-footed Boobies, if those characteristics vary over time. Instead, Blue-footed Boobies may not have enough information about clupeid abundance until after they begin to breed; this hypothesis predicts abandonment of breeding when clupeid intake continues to be low. Nazca Boobies provide an instructive contrast in this respect, continuing to attempt to breed after 1997, although with lower success, by switching prey (D. J. Anderson, unpublished data). Unlike Blue-footed Booby juveniles, which apparently remain in Galápagos until adulthood and depend on the local habitat, Nazca Booby juveniles leave Galápagos and spend several years off the Central American coast (Huyvaert and Anderson 2004). Under the "food-forjuvenile" hypothesis, voluntary abandonment based on local 
habitat conditions should be more likely for Blue-footed Boobies than for Nazca Boobies, and our data are consistent with this prediction, although better data are needed on the nature of breeding failures in Blue-footed Boobies. Our results showed that food capture predicted breeding motivation in Blue-footed Boobies, but that temporal variation was a more important predictor (Table 5), offering support for both a food-for-juvenile hypothesis and for a current food hypothesis.

Information regarding sardine abundance from the Peruvian Upwelling, east of Galápagos, shows that the sardine population there has declined almost to zero, on the same schedule as that which we infer for Galápagos. Fishery capture declined from thousands of tons in the 1990s to 0 tons since 2003, with anchovies showing a corresponding increase (IMARPE 2008a, b, Subsecretaria de Pesca de Ecuador 2011). Sardines cycle between high and low abundance with a period of 25 years in the Pacific, linked to the Pacific Decadal Oscillation (Chavez et al. 2003). The decline of sardines in the ETP started in the mid-1990s, matching the decline in breeding on two colonies in Galápagos (details in Appendix 3 in Anchundia 2013). Decline of sardines seems to not affect Blue-footed Boobies on the continental coast because they can switch to another high-energy fish like anchovies (Zavalaga et al. 2007), which are abundant during the low part of the sardine cycle in the Peruvian upwelling system but not in Galápagos. We suggest that Galápagos populations of clupeid cycle in abundance on the same schedule, and for the same reasons, as continental populations. Information about fish populations in Galápagos is poor, making it difficult to compare past and present populations, although some artisanal fishers have the perception that the bait fish (including clupeids) are less abundant than they were in the past (D. J. Anchundia, unpublished data). The contrast in breeding regime that we have identified (alternate long periods of good and poor breeding in Galápagos, consistency near the continent) can be expected to exert different selection pressures on the life histories of the two subspecies, with Galápagos birds rewarded for longevity to endure multidecade food shortages more so than are continental birds.

Introduced species have been one of the major threats for native or endemic species (Vitousek et al. 1997). Some have speculated that the increase in cat (Felis catus) numbers on some islands in recent decades may affect the breeding cycle of Blue-footed Boobies, with cats acting as a predator. However, islands with no cats (e.g., Española, Daphne Major, Seymour, and Fernandina) have essentially no current breeding, and Playa de los Perros is one of the most active, yet is on an island on which cats are abundant. Furthermore, Punta Vicente Roca historically has had a large presence of cats, yet Blue-footed Boobies bred in large numbers until the late 1990s. Little evidence exists for disease as a cause of population decline. During our 2-year study, including handling over 1000 birds, we saw no apparently sick birds. Avian blood parasites of the genus that causes avian malaria (Plasmodium) are present in Galápagos (Levin et al. 2009, 2013), though to date only Haemoproteus parasites have been identified in Sulids and none in Blue-footed Boobies (Quillfeldt et al. 2011). Blue-footed Boobies are known to have some parasites, including two endoparasites, a nematode (Contracecum sp.) and a trematode (Renicola $\mathrm{sp}$.). These parasites have low virulence in Brown Pelicans (Pelecanus occidentalis) and so probably play only a secondary role in population fluctuations (Greve et al. 1986).
In conclusion, our data indicate chronic poor breeding and a decline in population size of Galápagos Blue-footed Boobies, with circumstantial evidence implicating low availability of preferred prey since approximately 1997. During multidecadal periods of low sardine availability, the food base is sufficient for adults to exist but not to reproduce. In particular, we suggest that breeding failure is largely voluntary, triggered by the perception of breeders and potential breeders that the prey base cannot support the ineffective foraging of recently independent offspring. If breeding has been poor since the late 1990s, as we suspect, the age structure of Galápagos Blue-footed Boobies is probably biased strongly toward older individuals. Actuarial and reproductive senescence, documented in Blue-footed Boobies (Velando et al. 2006, Torres et al. 2011), can be expected to accelerate this iconic and genetically distinct population's decline via poor breeding ability and lower annual survival associated with old age, with important implications for biodiversity and local ecotourism.

Responses to this article can be read online at: http://www.ace-eco.org/issues/responses.php/650

\section{Acknowledgments:}

We thank: P. Cabrera, S. Cruz, F. Cunningham, M. Escobar, I. Haro, G. Jiménez-Uzcátegui, P. Medandra, and D. Mosquera, for assistance with the coastal survey and K. S. Anderson, M. Andres, J. Baque, A. Carrion, M. Escobar, M. Jaramillo, J. Liu, D. Mosquera, J. Moruve, A. Nieto, and Y. Vega for other assistance in the field; J. Baque for help identifying fish; K. E. Anderson for conducting the GIS analysis; P. and R. Grant for unpublished data from Daphne Major; L. Balance and R. Pitman for unpublished data on at-sea distribution; L. Anderson, M. Anderson, F. Estela, J. Grace, M. Silman, E. Tompkins, K. Hobson, and two anonymous reviewers for comments on earlier drafts; Galápagos Conservancy, Swiss Friends of Galápagos, and Galápagos Conservation Trust for funding; Galápagos National Park Service for permission to work in the Park; and the Charles Darwin Research Station and TAME Airline for logistic support. This material is based upon work supported under National Science Foundation Grants Nos. DEB 93045679, DEB 9629539, DEB 98-06606, DEB 0235818, and DEB 0842199 to D. J. Anderson. Field work conformed to Animal Care and Use Protocol A11-095 issued by Wake Forest University.

\section{LITERATURE CITED}

Anchundia, D. 2013. Population size of Blue-footed Boobies in Galápagos: evaluation of indications of population decline. Thesis, Wake Forest University, Winston-Salem, North Carolina, USA.

Anderson, D. J. 1989. Differential responses of boobies and other seabirds in the Galápagos to the 1986-87 El Niño-Southern Oscillation event. Marine Ecology Progress Series 52:209-216. http://dx.doi.org/10.3354/meps052209

Anderson, D. J. 1990. Evolution of obligate siblicide in boobies. 1: A test of the insurance egg hypothesis. American Naturalist 135:334-350. http://dx.doi.org/10.1086/285049

Anderson, D. J. 1991. Apparent predator-limited distribution of Galápagos Red-footed Boobies. Ibis 33:26-29. 
Avian Conservation and Ecology 9(1): 6

Anderson, D. J., and V. Apanius. 2003. Actuarial and reproductive senescence in a long-lived seabird: preliminary evidence. Experimental Gerontology 38:757-760. http://dx.doi.org/10.1016/ S0531-5565(03)00104-9

Anderson, D. J., and P. J. Hodum. 1993. Predator behavior favors clumped nesting in an oceanic seabird. Ecology 74:2462-2464. http://dx.doi.org/10.2307/1939597

Anderson, D. J., K. P Huyvaert, J. A. Awkerman, C. B. Proaño, W. B. Milstead, G. Jiménez-Uzcátegui, S. Cruz, and J. K. Grace. 2008. Population status of the critically endangered waved albatross (Phoebastria irrorata), 1999 to 2007. Endangered Species Research 5:185-192. http://dx.doi.org/10.3354/esr00089

Anderson, D. J., and R. E. Ricklefs. 1987. Radio-tracking Masked and Blue-footed Boobies in the Galápagos Islands. National Geographic Research 3:152-163.

Anderson, D. J., and R. E. Ricklefs. 1992. Brood size and food provisioning in Masked and Blue-footed Boobies (Sula spp). Ecology 73:1363-1374. http://dx.doi.org/10.2307/1940682

Anderson, D. R. 2008. Model based inference in the life sciences: a primer on evidence. Springer, New York, New York, USA. http:// dx.doi.org/10.1007/978-0-387-74075-1

Burnham, K. P., and D. R. Anderson. 2002. Model selection and multi-model inference: a practical information-theoretic approach. Springer Verlag, New York, New York, USA.

Burnham, K. P., D. R. Anderson, G. C. White, C. Brownie, and K. H. Pollock. 1987. Design and analysis methods for fish survival experiments based on release-recapture. American Fisheries Society Monograph 5.

Chavez, F. P., J. Ryan, S. Lluch-Cota, and M. Ñiquen. 2003. From anchovies to sardines and back: multidecadal change in the Pacific Ocean. Science 229:217-221. http://dx.doi.org/10.1126/science.1075880

Clifford, L. D., and D. J. Anderson. 2001. Food limitation explains most clutch size variation in the Nazca Booby. Journal of Animal Ecology 70:539-545 http://dx.doi.org/10.1046/j.1365-2656.2001.00521. $\mathrm{x}$

Cruz, L. L., R. A. Mcgill, S. J. Goodman, and K. C. Hamer. 2012. Stable isotope ratios of a tropical marine predator: confounding effects of nutritional status during growth. Marine Biology 159:873-880. http://dx.doi.org/10.1007/s00227-011-1864-7

Dellinger, T., and F. Trillmich. 1999. Fish prey of the sympatric Galápagos fur seals and sea lions: seasonal variation and niche separation. Canadian Journal of Zoology 77:1204-1216. http://dx. doi.org/10.1139/z99-095

Dentressangle, F., L. Boeck, and R. Torres. 2008. Maternal investment in eggs is affected by male feet colour and breeding conditions in the Blue-footed Booby, Sula nebouxii. Behavioural Ecology and Sociobiology 62:1899-1908. http://dx.doi.org/10.1007/ s00265-008-0620-6

Feldman, G. C. 1986. Patterns of phytoplankton production around the Galápagos Islands. Pages 77-106 in M. J. Bowman, C. M. Yentsch, and W. T. Peterson, editors. Tidal mixing and plankton dynamics. Springer, New York, New York, USA. http://dx.doi. org/10.1007/978-1-4612-4966-5_3
Froese, R., and D. Pauly, editors. 2013. FishBase World Wide Web electronic publication. Www.fishbase.org, version (02/2013).

Greve, J. H., H. F. Albers, B. Suto, and J. Grimes. 1986. Pathology of gastrointestinal helminthiasis in the Brown Pelican (Pelecanus occidentalis). Avian Diseases 30:482-487. http://dx.doi.org/10.2307/1590410

Grove, J. S., and R. J. Lavenberg. 1997. The fishes of the Galápagos Islands. Stanford University Press, Stanford, California, USA.

Harris, M. P. 1982. A field guide to the birds of Galápagos. Collins, London, UK.

Hayes, F. E., and W. S. Baker. 1989. Seabird distribution at sea in the Galápagos Islands: environmental correlations and associations with upwelled water. Colonial Waterbirds 12:60-66. http://dx.doi.org/10.2307/1521313

Houvenaghel, G. T. 1978. Oceanographic conditions in the Galápagos Archipelago and their relationships with life on the islands. Pages 181-200 in R. Boje and M. Tomczak, editors. Upwelling ecosystems. Springer, Berlin, Heidelberg, Germany. http://dx.doi.org/10.1007/978-3-642-66985-9_15

Hoyt, D. F. 1979. Practical methods of estimating volume and fresh weight of bird eggs. Auk 96:73-77.

Huggins, R. M. 1989. On the statistical analysis of capture experiments. Biometrika 76:133-140. http://dx.doi.org/10.1093/ biomet/76.1.133

Huggins, R. M. 1991. Some practical aspects of a conditional likelihood approach to capture experiments. Biometrics 47:725-732. http://dx.doi.org/10.2307/2532158

Huyvaert, K. P., and D. J. Anderson. 2004. Limited dispersal by Nazca Boobies, Sula granti. Journal of Avian Biology 35:46-53. http://dx.doi.org/10.1111/j.0908-8857.2004.03131.x

Instituto del Mar del Perú (IMARPE). 2008a. Desembarques de Sardinia en la costa Peruana (toneladas). IMARPE, Callao, Peru. [online] URL: http://www.imarpe.pe/imarpe/archivos/reportes/ imarpe_99-07_sardina.pdf

Instituto del Mar del Perú (IMARPE). 2008b. Estadísticas pesqueras. IMARPE, Callao, Peru. [online] URL: http://www. imarpe.pe/imarpe/index.php?id_seccion=I0131060300000000000000

Jiménez-Uzcátegui, G., B. Milstead, C. Márquez, J. Zabala, P. Buitrón, A. Llerena, and B. Fessl. 2006. Galápagos vertebrates: endangered status and conservation actions. Galápagos Report 2007:104-110.

Latorre, O. 1997. Galápagos: los primeros habitantes de algunas islas. Noticias de Galapagos 56:62-66.

Levin, I. I., D. C. Outlaw, F. H. Vargas, and P. G. Parker. 2009. Plasmodium blood parasite found in endangered Galapagos Penguins (Spheniscus mendiculus). Biological Conservation 142:3191-3195. http://dx.doi.org/10.1016/j.biocon.2009.06.017

Levin, I. I., P. Zwiers, S. L. Deem, E. A. Geest, J. M. Higashiguchi, T. A. Iezhova, G. Jiménez-Uuzcátegui, D. H. Kim, J. P. Morton, N. G. Perlut, R. B. Renfrew, E. H. R. Sari, G. Valkiunas, and P. G. Parker. 2013. Multiple lineages of avian malaria parasites (Plasmodium) in the Galapagos Islands and evidence for arrival via migratory birds. Conservation Biology 27:1366-1377. http://dx.doi. org/10.1111/cobi.12127 
Maness, T. J., and D. J. Anderson. 2013. Predictors in juvenile survival in birds. Ornithological Monographs No. 78. http://dx. doi.org/10.1525/om.2013.78.1.1

McClintock, B. T., and G. C. White. 2009. A less field-intensive robust design for estimating demographic parameters with markresight data. Ecology 90:313-320. http://dx.doi.org/10.1890/08-0973.1

Müllers, R. H. E., R. A. Navarro, R. J. Crawford, and L. G. Underhill. 2009. The importance of lipid-rich fish prey for cape gannet chick growth: are fishery discards an alternative? Journal of Marine Science 66:2244-2252.

Nelson, J. B. 1978. The Sulidae. Oxford University Press, Oxford, UK.

Nelson, J. B. 2005. Pelicans, cormorants, and their relatives. Oxford University Press, Oxford, UK.

Nichols, J. D., J. E. Hines, J. R. Sauer, F. W. Fallon, J. E. Fallon, and P. J. Heglund. 2000. A double-observer approach for estimating detection probability and abundance from point counts. Auk 117:393-408.

Oro, D., R. Torres, C. Rodríguez, and H. Drummond. 2010. Climatic influence on demographic parameters of a tropical seabird varies with age and sex. Ecology 91:1205-1214. http://dx. doi.org/10.1890/09-0939.1

Páez-Rosas, D., and D. Aurioles-Gamboa. 2010. Alimentary niche partitioning in the Galápagos sea lion (Zalophus wollebaeki). Marine Biology 157:2769-2781. http://dx.doi. org/10.1007/s00227-010-1535-0

Quillfeldt, P., E. Arriero, J. Martínez, J. F. Masello, and S. Merino. 2011. Prevalence of blood parasites in seabirds - a review. Frontiers in Zoology 8:26. http://dx.doi.org/10.1186/1742-9994-8-26

Ruiz, D. J., and M. Wolff. 2011. The Bolivar channel ecosystem of the Galapagos Marine Reserve: energy flow structure and role of keystone groups. Journal of Sea Research 66:123-134. http:// dx.doi.org/10.1016/j.seares.2011.05.006

Schew, W. A., and R. E. Ricklefs. 1998. Developmental plasticity. Pages 288-323 in J. M. Starck and R. E. Ricklefs, editors. Avian growth and development Oxford Ornithology Series, Oxford, UK.

Steadman, D. W. 1986. Holocene vertebrate fossils from Isla Floreana, Galápagos. Smithsonian Contributions to Zoology 413.

Steadman, D. W. 2006. Extinction and biogeography in tropical Pacific birds. University of Chicago Press, Chicago, Illinois, USA.

Subsecretaria de Pesca Ecuador. 2011. Desembarques de peces pelágicos pequeños 2000-2009. Ministerio del Ambiente, Quito, Ecuador. [online] URL: http://simce.ambiente.gob.ec/documentos/ desembarques-peces-pelagicos-pequenos-2000-2009

Szabo, J. K., N. Khwaja, S. T. Garnett, and S. H. M. Butchart. 2012. Global patterns and drivers of avian extinctions at the species and subspecies level. PLoS ONE 7:e47080. http://dx.doi. org/10.1371/journal.pone.0047080
Taylor, S. A., L. Maclagan, D. J. Anderson, and V. L. Friesen. 2011. Could specialization to cold-water upwelling systems influence gene flow and population differentiation in marine organisms? A case study using the Blue-footed Booby, Sula nebouxii. Journal of Biogeography 38:883-893. http://dx.doi. org/10.1111/j.1365-2699.2010.02445.x

Torres, R., H. Drummond, and A. Velando. 2011. Parental age and lifespan influence offspring recruitment: a long-term study in a seabird. PLoS ONE 6(11):e27245 http://dx.doi.org/10.1371/ journal.pone.0027245

Townsend, H. M., K. P. Huyvaert, P. J. Hodum, and D. J. Anderson. 2002. Nesting distributions of Galápagos boobies (Aves: Sulidae): an apparent case of amensalism. Oecologia 132:419-427. http://dx.doi.org/10.1007/s00442-002-0992-7

Vargas, H., C. Lougheed, and H. Snell. 2005. Population size and trends of the Galápagos Penguin (Spheniscus mendiculus). Ibis 147:367-374. http://dx.doi.org/10.1111/j.1474-919x.2005.00412. $\mathrm{x}$

Velando, A., H. Drummond, and R. Torres. 2006. Senescent birds redouble reproductive effort when ill: confirmation of the terminal investment hypothesis. Proceedings of the Royal Society B: Biological Sciences 273:1443-1448. http://dx.doi.org/10.1098/ rspb.2006.3480

Vitousek, P. M., C. M. D’Antonio, L. L. Loope, M. Rejmanek, and R. Westbrooks. 1997. Introduced species: a significant component of human-caused global change. New Zealand Journal of Ecology 21:1-16.

Weimerskirch, H., S. A. Shaffer, Y. Tremblay, D. P. Costa, H. Gadenne, A. Kato, Y. Ropert-Coudert, K. Sato, and D. Aurioles. 2009. Species- and sex-specific differences in foraging behaviour and foraging zones in Blue-footed and Brown Boobies in the Gulf of California. Marine Ecology Progress Series 391:267-278. http:// dx.doi.org/10.3354/meps07981

White, G. C., and K. P. Burnham. 1999. Program MARK: survival estimation from populations of marked animals. Bird Study 46 Supplement, 120-138. http://dx.doi.org/10.1080/00063659909477239

Witman, J. D., M. Brandt, and F. Smith. 2010. Coupling between subtidal prey and consumers along a mesoscale upwelling gradient in the Galápagos Islands. Ecological Monographs 80:153-177. http://dx.doi.org/10.1890/08-1922.1

Zavalaga, C. B., S. Benvenuti, L. Dall'antonia, and S. D. Emslie. 2007. Diving behavior of Blue-footed Boobies Sula nebouxii in northern Peru in relation to sex, body size and prey type. Marine Ecology Progress Series 336:291-303. http://dx.doi.org/10.3354/ meps336291
Editor-in-Chief: Keith A.Hobson Subject Editor: Alexander L.Bond
Sponsored by the Society of Canadian Ornithologists and Bird Studies Canada Parrainée par la Société des ornithologistes du Canada et Études d'oiseaux Canada

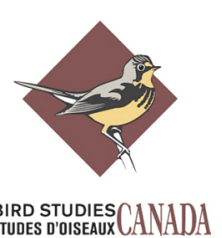




\section{Appendix 1}

Supplemental material for the paper "Chronic Lack of Breeding by Galápagos Blue-footed Boobies and Associated Population Decline” by David Anchundia, Kathryn Huyvaert, and David Anderson.

\section{Table A1.1}

Parameter estimates, standard errors (SE), and lower and upper 95\% confidence intervals (LCI, UCI) for detection probabilities for each island surveyed for Blue-footed Boobies in the Galápagos Archipelago, June 2012. Estimates are from the top-ranked model incorporating an effect of island on detection probability. Models were developed using a Huggins closed captures approach implemented in Program MARK. Islands with an estimate of " 1 ” indicate that the secondary observer did not observe any additional birds.

\begin{tabular}{lrrrr}
\multicolumn{1}{c}{ Island } & Estimate & \multicolumn{1}{c}{ SE } & \multicolumn{1}{c}{ LCI } & \multicolumn{1}{c}{ UCI } \\
Española & 0.907 & 0.026 & 0.843 & 0.947 \\
San Cristóbal & 0.983 & 0.007 & 0.964 & 0.992 \\
Floreana & 0.960 & 0.010 & 0.934 & 0.976 \\
Santa Fé & 0.983 & 0.012 & 0.932 & 0.996 \\
Santa Cruz & 0.964 & 0.006 & 0.949 & 0.974 \\
Pinzón & 1 & 0 & 1 & 1 \\
Rábida & 1 & 0 & 1 & 1 \\
Daphne Minor & 1 & 0 & 1 & 1 \\
Daphne Major & 1 & 0 & 1 & 1 \\
Seymour & 0.966 & 0.020 & 0.895 & 0.989 \\
Baltra & 0.974 & 0.013 & 0.931 & 0.990 \\
Santiago (all) & 0.991 & 0.003 & 0.981 & 0.996 \\
Santiago (north) & 0.973 & 0.019 & 0.896 & 0.994 \\
W. Isabela & 0.982 & 0.004 & 0.973 & 0.988 \\
E. Isabela & 0.967 & 0.009 & 0.945 & 0.980 \\
S. Isabela & 0.994 & 0.003 & 0.982 & 0.998 \\
Fernandina & 0.972 & 0.007 & 0.955 & 0.983
\end{tabular}


Table A1.2. Representation of prey items by weight in regurgitation samples. Numbers represent percentage of grams and sum to 100 vertically. The most important prey species for each column is identified with a box. For each colony, " 11 ” = 2011 and " 12 " = 2012 . "Total grams” is the total grams of fish collected during that year at that site.

Western Sites

\section{Central Sites}

P. Vicente

Fish Species

Sardine

(Sardinops sagax)

Black striped salema

(Xenocys jessiae)

Flying fish

(Exocoetidae sp.)

Creole

(Paranthias colonus)

Galápagos herring

(Opisthonema berlangai)

Mackeral

(Trachurus sp.)

Pacific silverstripe

(Hyporhamphus naos)

White salema

(Xenichthys agassiz)

Peruvian grunt (Anisotremus

capularis)

Panamic sergeant major

(Abudefduf troschelii)

Cortez rainbow (Thalassoma

ucasanum)

Carangidae

(Caranx sp.)

Total grams

\# birds that regurgitated

Total \# items

\begin{tabular}{|c|c|c|c|c|c|c|c|c|c|c|c|c|c|c|c|}
\hline \multicolumn{2}{|c|}{ Cabo Douglas } & \multicolumn{2}{|c|}{$\begin{array}{l}\text { P. Vicente } \\
\text { Roca }\end{array}$} & \multicolumn{4}{|c|}{ Central Sites } & \multicolumn{2}{|c|}{$\begin{array}{l}\text { Playa de los } \\
\text { Perros }\end{array}$} & \multicolumn{2}{|c|}{ Floreana } & \multicolumn{2}{|c|}{$\begin{array}{l}\text { Punta } \\
\text { Suárez }\end{array}$} & \multicolumn{2}{|c|}{ P. Pitt } \\
\hline 11 & 12 & 11 & 12 & 11 & 12 & 11 & 12 & 11 & 12 & 11 & 12 & 11 & 12 & 11 & 12 \\
\hline 14 & 0 & 47 & 0 & 67 & 76 & 43 & 66 & 0 & 26 & 49 & 90 & 0 & 0 & 0 & 0 \\
\hline 50 & 76 & 31 & 0 & 21 & 2 & 21 & 0 & 7 & 7 & 0 & 0 & 0 & 0 & 0 & 0 \\
\hline 3 & 0 & 14 & 0 & 6 & 0 & 0 & 0 & 55 & 38 & 0 & 0 & 100 & 57 & 0 & 92 \\
\hline 33 & 24 & 7 & 0 & 0 & 2 & 4 & 6 & 5 & 6 & 5 & 10 & 0 & 43 & 0 & 8 \\
\hline 0 & 0 & 0 & 0 & 0 & 19 & 30 & 24 & 0 & 0 & 0 & 0 & 0 & 0 & 0 & 0 \\
\hline 0 & 0 & 0 & 0 & 0 & 0 & 0 & 0 & 0 & 0 & 47 & 0 & 0 & 0 & 0 & 0 \\
\hline 0 & 0 & 0 & 0 & 0 & 0 & 0 & 2 & 26 & 2 & 0 & 0 & 0 & 0 & 0 & 0 \\
\hline 0 & 0 & 0 & 0 & 0 & 0 & 0 & 0 & 8 & 11 & 0 & 0 & 0 & 0 & 0 & 0 \\
\hline 0 & 0 & 0 & 0 & 0 & 0 & 0 & 0 & 0 & 9 & 0 & 0 & 0 & 0 & 0 & 0 \\
\hline 0 & 0 & 0 & 0 & 6 & 0 & 2 & 0 & 0 & 0 & 0 & 0 & 0 & 0 & 0 & 0 \\
\hline 0 & 0 & 0 & 0 & 0 & 0 & 0 & 1 & 0 & 0 & 0 & 0 & 0 & 0 & 0 & 0 \\
\hline 0 & 0 & 0 & 0 & 0 & 0 & 0 & 1 & 0 & 0 & 0 & 0 & 0 & 0 & 0 & 0 \\
\hline 1890 & 812 & 2352 & 0 & 825 & 2368 & 1931 & 3010 & 1850 & 1593 & 242 & 343 & 46 & 425 & 0 & 477 \\
\hline 19 & 8 & 38 & 0 & 11 & 28 & 13 & 28 & 15 & 30 & 5 & 4 & 2 & 9 & 7 & 4 \\
\hline 115 & 19 & 106 & 0 & 69 & 112 & 83 & 206 & 57 & 98 & 15 & 14 & 2 & 15 & 0 & 24 \\
\hline
\end{tabular}

